\title{
Fotografia jako narzędzie mediatyzacji wojny w mediach społecznościowych - na przykładzie fotografii konfliktu na wschodniej Ukrainie
}

\section{Wprowadzenie}

Do epokach kultury mówionej oraz kultury słowa pisanego mamy obecnie do czynienia z intensyfikacją kultury wizualnej i coraz szerszym przenikaniem form wizualnych do sfer poznawczych człowieka. Obrazy przenoszą szereg nowych elementów istotnych w komunikacji, m.in. zakodowane informacje, znaczenia, wiedzę, emocje, doznania estetyczne i wartości. W epoce obrazowej zwłaszcza dwa historyczne wydarzenia uznać należy za przełomowe: wynalezienie fotografii oraz odkrycie cyfrowego zapisu - kopiowania i przenoszenia obrazów wraz z możliwością ich multiplikowania. Dzięki tym dokonaniom szybko są przekraczane granice czasu i przestrzeni w rozpowszechnianiu form wizualnych, zaś zakres ich odbioru staje się nieograniczony ${ }^{1}$. Wprawdzie fotografia jako zjawisko kulturowe zdobyła uznanie stosunkowo niedawno - w latach siedemdziesiątych XX wieku i na ten okres przypada jej oddzielenie się od form czysto użytkowych oraz naukowa instytucjonalizacja. W efekcie fotografia stała się wyjątkowym narzędziem dokumentacji nowoczesnych społeczeństw i wciąż dynamicznie doskonali się w warstwie parametrów technicznych, aby sprostać wyzwaniom społeczeństwa informacyjnego.

\footnotetext{
* DR HAB. JUstyna SzUlich-KaŁUŻa - medioznawca, socjolog mediów, prof. KUL, dyrektor Instytut Dziennikarstwa i Komunikacji Społecznej KUL, kierownik Katedry Komunikacji Wizualnej, kontakt: justyna.szulich-kaluza@kul.pl

${ }^{1}$ M. Hopfinger, Kultura współczesna - audiowizualność, Warszawa 1985, s. 13.
} 
Refleksje dotyczące fotografii jako narzędzia medialnego, upowszechniającego wiedzę o współczesnych konfliktach wojennych wydaje się być interesującym i inspirującym przykładem dokumentowania rzeczywistości. Wybór materiału do badań własnych nie powinien budzić zastrzeżeń. Fotografie publikowane na portalach społecznościach należą do najbardziej popularnych wizualizacji publicznych, które mają zwrócić na siebie uwagę licznej, choć dość specyficznej publiczności złożonej z anonimowej zbiorowości użytkowników. Zazwyczaj nie są oni związani relacjami rzeczywistymi, tylko zapośredniczonymi przez nowoczesne technologie w przestrzeniach wirtualnych. Oczywiście te osoby może łączyć podobna kultura, doświadczenia życiowe, sytuacja ekonomiczna, polityczna i przestrzeń określonych wpływów². Media społecznościowe stają się swoistym doświadczeniem zbiorowym i wspólnie podzielaną reprezentacją pamięci, gustu, historii, wskaźników tożsamości, życia codziennego, opinii oraz ocen. Użytkownicy grupowo artykułują nową zdigitalizowaną estetykę codzienności ${ }^{3}$. Obejmuje ona wiele sfer życia społecznego, w tym także sytuacje globalnych konfliktów. Najważniejszą cechą komunikatów wizualnych, o których tu mowa jest ich procesualny charakter - otwarty na twórcze dokonania autorów. W kampaniach informacyjnych zwłaszcza polityczno-społecznych prowadzonych na ogólnodostępnych portalach społecznościowych do głosu dochodzą różnorodne techniki dezinformacji, a nawet manipulacji, prowokacji zarówno słownej, jak i obrazowej. Przekazy obrazowe są wygodnym i skutecznym sposobem uzyskiwania pożądanych efektów $\mathrm{u}$ audytorium odbiorców przynajmniej z trzech powodów: po pierwsze, materiały wizualne bardzo dobrze wpisują się w mechanizmy emocjonalnego pobudzenia pożądanych sposobów odczytywania znaczeń, celem stopniowego eliminowania zachowań racjonalnych; po drugie, przekaz obrazowy jest prosty i zrozumiały, nie ma potrzeby specjalnego przygotowania odbiorcy, by została przyjęta i zaakceptowana pożądana wizja przebiegu zdarzeń; po trzecie, obraz jest skutecznym narzędziem kreowania wątpliwej, nieprawdziwej rzeczywistości poprzez manipulacje zawartością, np. gdy treści na fotografiach lub filmach nie zgadzają się z informacjami, które ilustrują, lub manipulacje źródłem, najczęściej poprzez brak jego podania; trzecia forma manipulacji to fałszywa zawartość czyli utrwalanie nieprawdziwych sytuacji, czasami „nieprawdziwych”, podstawionych bohaterów o zmiennych tożsamościach. Nowym kontekstem charakterystycznym dla fotografii publikowanych w mediach społecznościowych jest aspekt autora. Może nim być każdy amator,

${ }^{2}$ M. Villi, J. Matikainen, Wiadomość zdjęciowa jako forma komunikacji wspólnotowej, w: Fotospołeczeństwo. Antologia tekstów z socjologii wizualnej, red. M. Bogunia-Borowska, P. Sztompka, Kraków 2012, s. 527.

${ }^{3}$ S. Murray, Czy fotografie mówia prawdę, w: Fotospołeczeństwo. Antologia tekstów z socjologii wizualnej, red. M. Bogunia-Borowska, P. Sztompka, Kraków 2012, s. 481. 
niekoniecznie $\mathrm{z}$ fotograficznym przygotowaniem, który powinien spełniać jeden warunek - mianowicie być naocznym świadkiem dokumentowanych wydarzeń.

$\mathrm{W}$ realizowanym projekcie badawczym ${ }^{4}$ interesowała autorkę narracja wizualna w wybranych mediach społecznościowych tematyzująca konflikt rosyjsko-ukraiński. Najbardziej popularnymi ukraińskimi i rosyjskimi portalami według kryterium liczby użytkowników i liczby polubień okazały się Facebook i Vkontakte. Posty ilustrowane fotografiami opublikowane były w okresie najintensywniejszych działań wojennych - od 1.04.2014 r. do 31.12.2014 r. w języku angielskim, rosyjskim i ukraińskim. Wyniki analiz własnych posłużyły do poszukiwań odpowiedzi na pytania bardziej szczegółowe, których zakres zamknąć można w następujących polach problemowych:

1. stylistyka i formy kompozycyjne fotograficznej dokumentacji działań wojennych,

2. realizm czy manipulacja w fotograficznych narracjach wojennych,

3. charakterystyka strategii przekazów wojennych w mediach społecznościowych.

Powyższe zagadnienia posłużą do strukturalizacji treści artykułu. W pierwszej części uwaga poświęcona będzie ogólnej specyfice fotografii wojennych i zmieniającym się sposobom pracy fotografów dokumentujących działania wojenne. Następnie zasadnicza część opracowania przybliży wyniki analiz własnych.

\section{Fotografowanie wojny - ustalenia teoretyczne}

Historia fotografii wojennej sięga lat 40. i 50. XIX wieku, choć właściwie dopiero w czasie trwania I wojny światowej, gdy aparaty fotograficzne zmniejszyły swoje wymiary i stały się bardziej mobilne upowszechniły się fotografie $z$ wojen. $\mathrm{Z}$ uwagi na podjęty temat warto przyjrzeć się relacji na linii fotograf - działania wojenne w kontekście najnowszych światowych konfliktów zbrojnych: w Wietnamie, na Falklandach i w Zatoce Perskiej. Jako uzupełnienie przytoczone zostaną ciekawe spostrzeżenia na temat pracy fotografów wojennych Andre Rouille, autora licznych prac z zakresu fotografii jako dokumentu.

Wojna w Wietnamie na Półwyspie Indochińskim w latach 1957-1975 stanowiła apogeum fotografii akcji. Była pierwszą i zarazem ostatnią, szeroko fotografowaną i pokazywaną w telewizji. Fotografowie upodobnieni do żoł-

${ }^{4}$ Opracowanie jest poszerzoną analizą danych z badań w kontekście mediatyzacji wojny, które były wykonane na potrzebę międzynarodowego projektu: Framing of the Ukraina-Russia conflict in media. Representation of the conflict in discourse on the Facebook, VKontakte, and Internet portals: DELFI, correspondent.net, Pravda.com.ua, kyivpost.com and onet.pl, zrealizowanego w latach 2014-2015. Szerzej o projekcie w publikacji: Framing of the Ukraine - Russia conflict in online and social media, red. Robert Szwed, Ryga 2016. 
nierzy, w wojskowych mundurach, wyruszali na akcje zbrojne, wskakiwali do helikopterów, przekazywali filmy fotograficzne $\mathrm{z}$ frontu za pomocą poczty polowej. Fotografia utożsamiana więc była $\mathrm{z}$ bezpośrednim zaangażowaniem, z działaniem, przygodą i niebezpieczeństwem. Fotografowie za pomocą swoich obiektywów w niespotykany dotąd sposób dokumentowali okropieństwa wojny. Wojna przyczyniła się do sukcesu fotografii - akcji naznaczając ją niezatartym piętnem śmierci i krwi. Wojskowi i rządzący, którzy doświadczyli mediatyzacji wojny, zrozumieli że ze strategicznego punktu widzenia kontrolowanie obrazów konfliktów zbrojnych oraz uniemożliwienie fotografom i operatorom telewizyjnym nieskrępowanego dostępu do pola bitwy jest niezwykle ważne ${ }^{5}$.

Wojna na Falklandach między Argentyną i Wielka Brytanią w 1982 roku wyznaczyła kierunek bardziej restrykcyjnej polityki w stosunku do rejestrowanych obrazów. Tylko dwóch fotoreporterów otrzymało oficjalną zgodę na towarzyszenie brytyjskim oddziałom. Działania wojenne nie były zatem starannie i szczegółowo dokumentowane przez fotografów. $\mathrm{Z}$ tamtego okresu pochodzi nowa formuła $w$ pracy dziennikarskiej - reportaż $w$ formie zorganizowanej podróży. Fotografowie, zapraszani przez władze wojskowe, udawali się na front, a ich praca była pod całkowitą ich kontrolą.

Przede wszystkim wojna w Zatoce Perskiej z 1991 utrwaliła nowy sposób kontrolowania obrazu. Potwierdziła, że od tej pory siły wojskowe w pełni będą kontrolować wytwarzanie, jak i rozpowszechnianie zdjęć w skali całego świata. Konflikt zbrojny nie był wojną bez fotografii, ale wojną w której pojawiało się coś, co możemy nazwać „antyzdjęciem”. Strategiczną rolę odegrało przedstawianie rzeczywistości w sposób całkowicie kontrolowany przez generalny sztab wojskowy. Tradycyjne obrazy przedstawiające walki i ofiary zastąpiono zdjęciami wykonanymi techniką cyfrową z samolotów i satelitów. Lev Manovich nazwał zdjęcia satelitarne „inteligentną" bronią „utelewizyjnionej' wojny w Zatoce Perskiej, która bez trudu rozpoznaje cel i podąża za nim lub doń zmierza ${ }^{6}$. Strategia wojskowa została więc wzmocniona przez polityczną strategię przedstawiania, w której podstawowym operatorem stała się amerykańska telewizja CNN. Owa figuratywna strategia zmierzała do tego, aby zapobiec sytuacji, jaka miała miejsce w Wietnamie, kiedy to krew i ofiary zajmowały bardzo dużo miejsca w przekazach medialnych. Zdając sobie doskonale sprawę z wrażenia, jakie mogą one wywrzeć na opinii publicznej, decydenci wojskowi systematycznie i pieczołowicie kontrolowali fotograficzne obrazy, eliminując wszelkie zdjęcia wykonane na ziemi, obrazy ciał i ofiar, odrzucając wszelkie widoczne przejawy walk ukazując cały ten konflikt zbrojny w formie gry komputerowej. Dzięki

\footnotetext{
${ }^{5}$ A. Rouille, Fotografia między dokumentem a sztuka współczesna, Kraków 2007, s.160.

${ }^{6}$ L. Manovich, Paradoks fotografii cyfrowej, w: Fotospołeczeństwo. Antologia tekstów z socjologii wizualnej, red. M. Bogunia-Borowska, P. Sztompka, Kraków 2012, s. 536.
} 
temu wojna stawała się czymś abstrakcyjnym i możliwym do zaakceptowania ${ }^{7}$. Warto odnieść powyższe ustalenia do charakterystyki medialnych przekazów fotograficznych dotyczących współczesnego konfliktu rosyjsko-ukraińskiego.

\section{Fotografie konfliktu na Ukrainie na Facebooku i Vkontakte - ustalenia metodologiczne analizy własnej}

W analizie fotografii wykorzystano technikę ilościowej analizy zawartości oraz analizę semiotyczną. Na potrzebę analizy ilościowej opracowano klucz kategoryzacyjny, obejmujący kategorie formalne i merytoryczne służące do opisu zdjęć. Analizą szczegółową objęte zostały fotografie, które użytkownicy umieścili na wyselekcjonowanych postach portali społecznościowych Facebook i Vkontakte w okresie od 1.04.2014 r. do 31.12.2014 r. W doborze materiału badawczego posłużono się trzema podstawowymi kryteriami selekcji postów:

1. według słów kluczowych: Krym/Крым/Crimea,Донбасc/Donbass, Maydan/Майдан, АTO

2. według liczby użytkowników podpisanych (kategoria na portalu Vkontakte)

3. według liczby polubień (kategoria na portalu Facebook)

Ogółem materiał badawczy stanowiło 197 fotografii, w tym 112 opublikowanych na portalu Facebook i 85 na portalu Vkontakte ${ }^{8}$.

\section{Stylistyka i formy kompozycyjne} fotograficznej dokumentacji działań wojennych

Zdjęcia towarzyszące komentarzom na portalach społecznościowych potraktowane zostały jako kody wizualne służące wywołaniu określonej wizji konfliktu u osoby oglądającej. Analiza zawartości pozwoli na doprecyzowanie tej wizji. W pierwszym etapie analizy przyjrzymy się cechom formalnym analizowanych fotografii - zróżnicowaniu gatunkowemu zdjęć. Posłużono się tradycyjnym podziałem na gatunki informacyjne (portrety, fotografie sytuacyjne, infografika, fotografie sytuacyjne) oraz publicystyczne (fotoreportaż).

A. Rouille, Fotografia między dokumentem a sztuka współczesną, s.162.

${ }^{8}$ Fotografie pochodzą ze stron: https://www.facebook.com/RussianCrimea, https://www. facebook.com/EuroMaydan, https://www.facebook.com/radiosvobodakrym.org, http://vk.com/ sdamnaleto, http://v.com/budspravjnimukraincem ,http://vk.com/vosto4nuyfront, http://vk.com/ revolution 
Tab. nr 1 .

\begin{tabular}{|l|c|c|c|c|c|}
\hline \multicolumn{7}{|c|}{ Gatunek fotografii } \\
\hline \multicolumn{1}{|c|}{ Nazwa portalu } & portret & sytuacyjna & fotoreportaż & infografika & satelitarna \\
\hline $\begin{array}{l}\text { Facebook } \\
\text { АнтиМайдан }\end{array}$ & 10 & 9 & 0 & 3 & 1 \\
\hline $\begin{array}{l}\text { Facebook } \\
\text { ЄвроМайдан }\end{array}$ & 13 & 16 & 0 & 6 & 1 \\
\hline $\begin{array}{l}\text { Facebook Russian } \\
\text { Сrimea }\end{array}$ & 2 & 11 & 0 & 4 & 1 \\
\hline $\begin{array}{l}\text { Facebook Крым } \\
\text { Реалии }\end{array}$ & 8 & 24 & 0 & 3 & 0 \\
\hline suma & $\mathbf{3 3}$ & $\mathbf{6 0}$ & $\mathbf{0}$ & $\mathbf{1 6}$ & $\mathbf{3}$ \\
\hline $\begin{array}{l}\text { Vkоntaktе Україна } \\
\text { понад усе! }\end{array}$ & 12 & 16 & 0 & 3 & 0 \\
\hline $\begin{array}{l}\text { Vkоntaktе } \\
\text { Новости Донбасса }\end{array}$ & 7 & 16 & 0 & 6 & 0 \\
\hline Vkоntaktе Крым & 3 & 12 & 0 & 0 & 0 \\
\hline $\begin{array}{l}\text { Vkоntaktе Ми } \\
\text { Українці }\end{array}$ & 1 & 4 & 0 & 4 & 0 \\
\hline suma & $\mathbf{2 4}$ & $\mathbf{4 8}$ & $\mathbf{0}$ & $\mathbf{1 3}$ & $\mathbf{0}$ \\
\hline
\end{tabular}

Źródło: opracowanie własne

Zarówno na portalu Facebook jak i na Vkontakte dominują fotografie informacyjne: sytuacyjne i portretowe. To gatunki najlepiej oddające procesualny tj. rozwojowy charakter konfliktu i jednocześnie dokumentujące głównych bohaterów konfliktu: cywilów, dowództwo militarne i władze polityczne.

Kolejną cechą prezentowanych fotografii jest źródło ich pochodzenia.

Tab. nr 2 .

\begin{tabular}{|l|c|c|c|c|}
\hline \multicolumn{1}{|c|}{ Źródło/autorstwo } \\
\hline Nazwa portalu & autorskie & agencyjne & $\begin{array}{c}\text { ze źródeł } \\
\text { zewnętrznych }\end{array}$ & bez autora \\
\hline Facebook АнтиМайдан & 0 & 0 & 4 & 25 \\
\hline Facebook ЄвроМайдан & 0 & 1 & 25 & 11 \\
\hline Facebook Russian Сrimea & 1 & 0 & 1 & 38 \\
\hline Facebook Крым Реалии & 1 & 0 & 34 & 1 \\
\hline suma & $\mathbf{2}$ & $\mathbf{1}$ & $\mathbf{6 4}$ & $\mathbf{7 5}$ \\
\hline
\end{tabular}




\begin{tabular}{|l|c|c|c|c|}
\hline $\begin{array}{l}\text { Vkontakte Україна - } \\
\text { понад усе! }\end{array}$ & 0 & 0 & 19 & 23 \\
\hline $\begin{array}{l}\text { Vkontakte Новости } \\
\text { Донбасса }\end{array}$ & 0 & 0 & 19 & 20 \\
\hline Vkontakte Крым & 0 & 0 & 9 & 25 \\
\hline Vkontakte Ми Українці & 0 & 0 & 8 & 12 \\
\hline suma & $\mathbf{0}$ & $\mathbf{0}$ & $\mathbf{5 5}$ & $\mathbf{8 0}$ \\
\hline
\end{tabular}

Źródło: opracowanie własne

Na obu portalach dominują dwie grupy zdjęć. Są to fotografie anonimowe bez podania autora oraz fotografie pochodzące ze źródeł zewnętrznych. Źródłami zewnętrznymi są adresy stron internetowych lub konkretne linki użytkowników, z których rekapitulowane są materiały na posty. Znikoma liczba lub brak zdjęć autorskich i agencyjnych wskazuje na niższą wiarygodność upowszechnianych materiałów. Zawsze bowiem konkretne nazwisko, funkcja zawodowa - fotoreportera, albo pozycja społeczna autora zdjęcia są gwarantem prawdziwości i odpowiedzialności za przekaz. W materiale badawczym znaleziono dwa przypadki fotografii agencyjnych wizualizujących ukraińskich nacjonalistów i prorosyjskie siły militarne na Krymie.

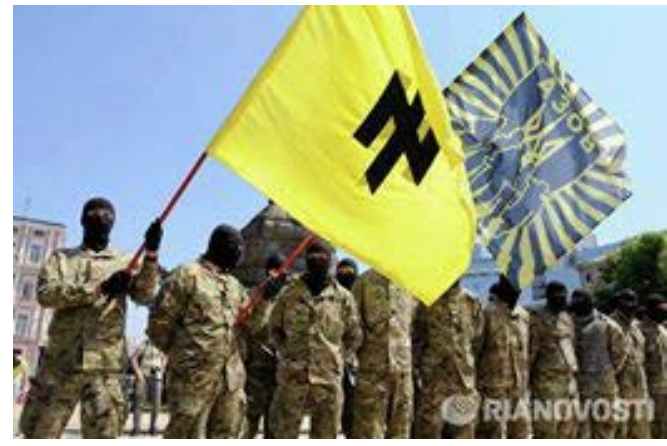

Facebook АнтиМайдан

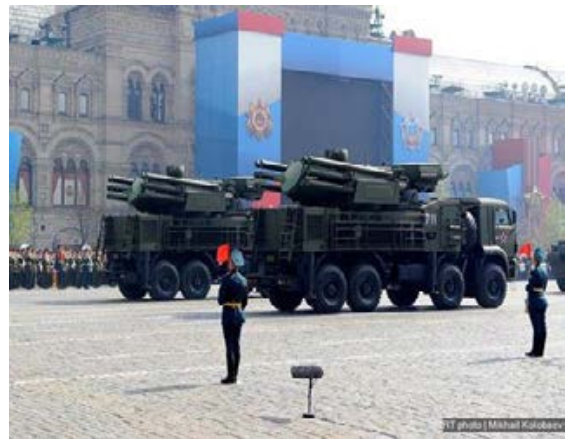

Facebook Russian Crimea

Osoby prezentowane na fotografiach można uporządkować w kilka kategorii, które wyszczególnione są w poniższej tabeli. 
Tab. nr 3 .

\begin{tabular}{|c|c|c|c|c|c|c|c|c|}
\hline \multicolumn{9}{|c|}{ Osoby na fotografiach } \\
\hline $\begin{array}{l}\text { Nazwa } \\
\text { portalu }\end{array}$ & 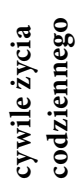 & $\stackrel{\grave{0}}{:}$ & 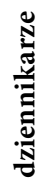 & 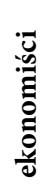 & 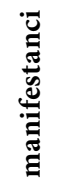 & 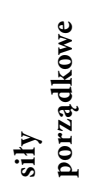 & 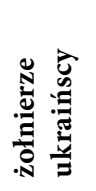 & 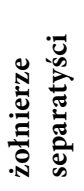 \\
\hline $\begin{array}{l}\text { Facebook } \\
\text { АнтиМайдан }\end{array}$ & 6 & 9 & 0 & 0 & 3 & 0 & 2 & 2 \\
\hline $\begin{array}{l}\text { Facebook } \\
\Theta_{\text {вроМайдан }}\end{array}$ & 6 & 8 & 0 & 1 & 0 & 0 & 4 & 4 \\
\hline $\begin{array}{l}\text { Facebook Russian } \\
\text { Crimea }\end{array}$ & 1 & 11 & 0 & 0 & 3 & 1 & 0 & 8 \\
\hline $\begin{array}{l}\text { Facebook Крым } \\
\text { Реалии }\end{array}$ & 10 & 9 & 1 & 0 & 4 & 2 & 0 & 0 \\
\hline suma & 23 & 37 & 1 & 1 & 10 & 3 & 6 & 14 \\
\hline $\begin{array}{l}\text { Vkontakte Україна } \\
\text { - понад усе! }\end{array}$ & 4 & 12 & 0 & 2 & 1 & 1 & 8 & 3 \\
\hline $\begin{array}{l}\text { Vkontakte } \\
\text { Новости Донбасса }\end{array}$ & 3 & 12 & 0 & 2 & 1 & 1 & 8 & 3 \\
\hline Vkontakte Крым & 5 & 14 & 1 & 0 & 4 & 1 & 2 & 3 \\
\hline $\begin{array}{l}\text { Vkontakte Ми } \\
\text { Українці }\end{array}$ & 2 & 5 & 0 & 0 & 0 & 0 & 4 & 0 \\
\hline suma & 12 & 43 & 1 & 4 & 6 & 3 & 22 & 9 \\
\hline
\end{tabular}

Źródło: opracowanie własne

Na fotografiach najczęściej pojawiają się politycy i cywile. W dalszej kolejności żołnierze - na portalu Facebook jest więcej rosyjskich, na Vkontakte - ukraińskich. Przewagę liczebności fotografii żołnierzy ukraińskich na Vkontakte można tłumaczyć tym, że target jego użytkowników raczej skłania się do twierdzenia, że to Ukraina jest agresorem. Tezę publicznie potwierdzały władze rosyjskie i ich medialny dyskurs zgodnie z którym Rosja nie zaatakowała zbrojnie Ukrainy, a żołnierze rosyjscy odbywają ćwiczenia wojskowe przy granicy z Ukrainą. Wizualizacje polityków jako aktorów konfliktów wojennych wskazują także na fakt, że współczesne wojny w mediach wytwarzają iluzję niezbędności polityki jako podstawowego elementu strategii wojennych' ${ }^{9}$. Zanika też klasyczny podział na żołnierzy i cywilów, mundur znika z pola walki - każdy członek

${ }^{9}$ Ch. Barker, Studia kulturowe. Teoria i praktyka, Kraków 2005, s.42. 
społeczeństwa jest lub może stać się żołnierzem realnie lub potencjalnie ${ }^{10}$. Śmierć i zabijanie nie są eksponowane na fotografiach. Wyjątek stanowią trzy zdjęcia o bardzo realistycznym charakterze zapisu: jedno to zwłoki rosyjskich ochotników, drugie - zwłoki kobiety w sklepie, trzecie szczątki ofiar samolotu Boeing 777. Wszystkie opublikowane na portalu Vkontakte Новости Донбасса.

Można zatem mówić o tendencji zaprzestania upowszechniania w mediach społecznościowych fotograficznej estetyzacji wojennych krwawych działań przemocowych i represyjnych, z jaką spotykaliśmy się przy okazji wcześniejszego dokumentowania działań wojennych np. podczas II wojny światowej. Estetyzacja taka czyniła zabijanie powinnością wobec ojczyzny, była więc czymś wzniosłym i swoiście pięknym. Zjawisko estetyzacji śmierci dobrze ilustrują przykłady z okresu II wojny światowej - niemieccy żołnierze bez oporów fotografowali się na tle rozstrzelanych czy pomordowanych ofiar, gdyż te czyny uwznioślały ich jako dobrych synów Rzeszy Niemieckiej ${ }^{11}$.

Kolejnymi kategoriami badawczymi są obiekty rejestrowane na zdjęciach.

Tab. nr 4 .

\begin{tabular}{|c|c|c|c|c|c|c|c|}
\hline \multicolumn{8}{|c|}{ Obiekty na fotografiach } \\
\hline Nazwa portalu & 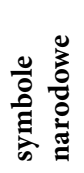 & 旋 & 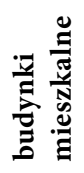 & 昰 & & 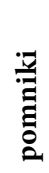 & כ) \\
\hline Facebook АнтиМайдан & 14 & 2 & 3 & 1 & 4 & 0 & 0 \\
\hline Facebook ЄвроМайдан & 12 & 4 & 2 & 1 & 6 & 0 & 0 \\
\hline $\begin{array}{l}\text { Vkontakte Новости } \\
\text { Донбасса }\end{array}$ & 18 & 0 & 3 & 1 & 9 & 0 & 1 \\
\hline $\begin{array}{l}\text { Facebook } \\
\text { Russian Crimea }\end{array}$ & 26 & 1 & 0 & 0 & 10 & 0 & 1 \\
\hline Facebook Крым Реалии & 12 & 2 & 0 & 0 & 1 & 0 & 0 \\
\hline suma & 64 & 9 & 5 & 2 & 21 & $\mathbf{0}$ & 1 \\
\hline $\begin{array}{l}\text { Vkontakte Україна - } \\
\text { понад усе! }\end{array}$ & 14 & 1 & 0 & 2 & 9 & 0 & 0 \\
\hline $\begin{array}{l}\text { Vkontakte Новости } \\
\text { Донбасса }\end{array}$ & 18 & 0 & 3 & 1 & 9 & 0 & 1 \\
\hline
\end{tabular}

${ }^{10} \mathrm{H}$. Yee-Kuang, The "transformation of war" debate; Through the looking glass of Urlich Beck's World Risk Society, „International Relations”, 2006, vol. 20, no.1 s.71. 69-91

${ }^{11}$ J. Kurowicki, Fotografia jako zjawisko estetyczne, Toruń 2000, s. 124. 


\begin{tabular}{|c|c|c|c|c|c|c|c|}
\hline \multicolumn{8}{|c|}{ Obiekty na fotografiach } \\
\hline Nazwa portalu & 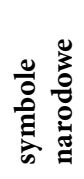 & 莺 & 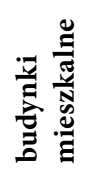 & 苞 & •气 & 竎 & כ \\
\hline Vkontakte Крым & 22 & 2 & 0 & 0 & 3 & 0 & 0 \\
\hline Vkontakte Ми Українці & 13 & 0 & 1 & 0 & 2 & 1 & 0 \\
\hline suma & 67 & 3 & 4 & 3 & 23 & 1 & 1 \\
\hline
\end{tabular}

Źródło: opracowanie własne

W wizualizacjach największe liczebności uzyskały symbole narodowe i uzbrojenie militarne. Współczesna wojna jest zatem wciąż pokazem militarnej siły, a nową jej odsłoną okazała się walka na symbole.

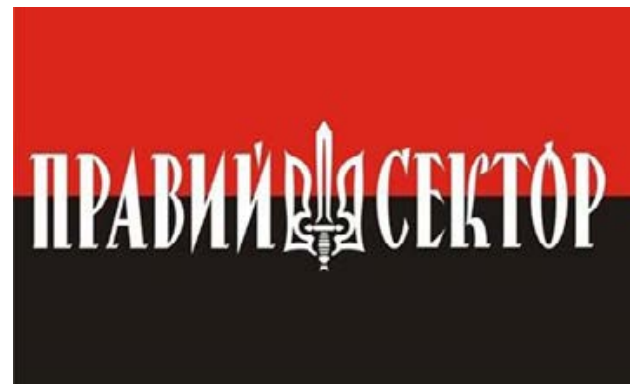

Facebook ЄвроМайдан

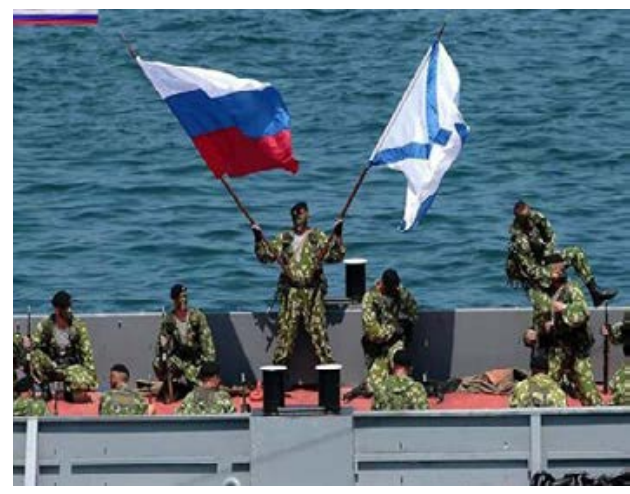

Facebook Russian Crimea

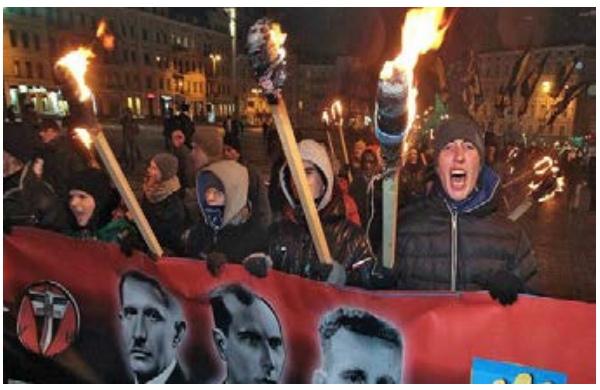

Vkontakte Новости Донбасса

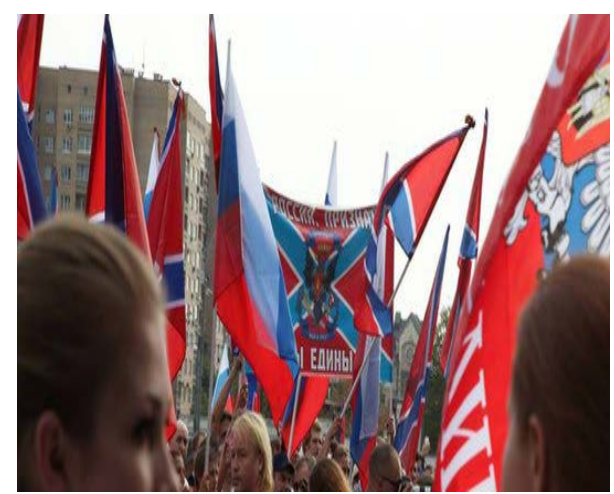

Vkontakte Новости Донбасса 


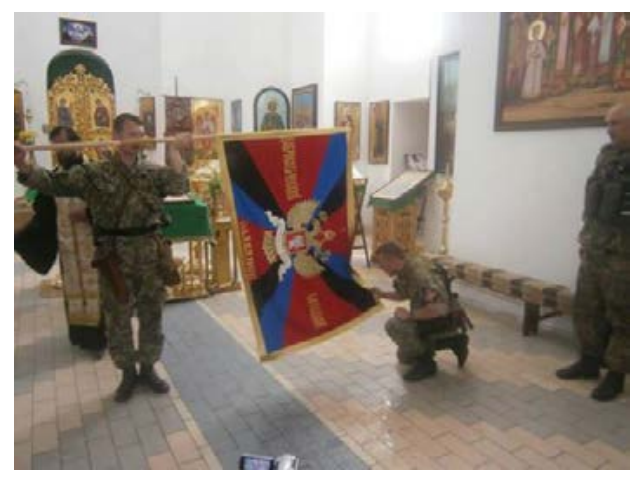

Facebook Russian Crimea

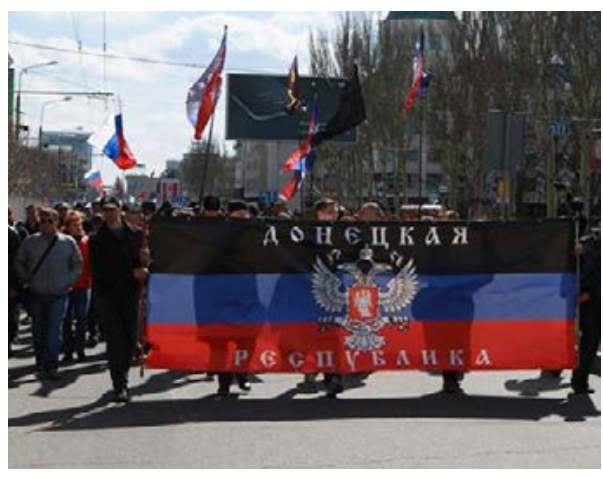

Facebook Russian Crimea

Symbole narodowe to istotne elementy, które najbardziej poruszają emocjonalnie odbiorców. Funkcja emocjonalna fotografii w jej wymiarze ekspresywnym (czyli pokazanie zaangażowania emocjonalnego autora w postaci sympatii lub jej braku w stosunku do prezentowanych treści) oraz impresywnym (czyli wywołanie na odbiorcy odpowiedniego wrażenia, oddziaływanie na uczucia, sądy, przekonania, wzbudzenie ciekawości) to kolejne przedmioty refleksji. Okazało się jednak, że te zagadnienia badawcze trudno eksplorować. Bohaterowie na fotografiach rzadko wyrażają emocje, na analizowanych fotografiach liczebną przewagę uzyskała kategoria: twarz neutralna. Trudno także ocenić stosunek autora do prezentowanych ujęć bez uzupełniających informacji o kontekście odautorskim, a zdobycie takich danych w realizowanym projekcie okazało się zadaniem trudnym do wykonania.

Poniższa tabela ilustruje próbę kategoryzacji emocji na fotografiach:

Tab. nr 5 .

\begin{tabular}{|c|c|c|c|c|c|c|c|}
\hline \multicolumn{8}{|c|}{ Emocje na fotografiach } \\
\hline $\begin{array}{l}\text { Nazwa } \\
\text { portalu }\end{array}$ & 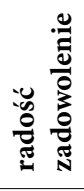 & 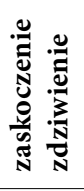 & 范 & 冚 & 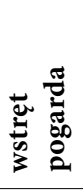 & 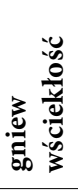 & 逽 \\
\hline $\begin{array}{l}\text { Facebook } \\
\text { АнтиМайдан }\end{array}$ & 3 & 0 & 1 & 0 & 3 & 0 & 14 \\
\hline $\begin{array}{l}\text { Facebook } \\
\Theta_{\text {вроМайдан }}\end{array}$ & 1 & 0 & 1 & 0 & 0 & 0 & 14 \\
\hline $\begin{array}{l}\text { Facebook Rus- } \\
\text { sian Crimea }\end{array}$ & 3 & 0 & 1 & 0 & 2 & 1 & 15 \\
\hline
\end{tabular}




\begin{tabular}{|c|c|c|c|c|c|c|c|}
\hline \multicolumn{8}{|c|}{ Emocje na fotografiach } \\
\hline $\begin{array}{l}\text { Nazwa } \\
\text { portalu }\end{array}$ & 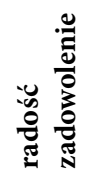 & 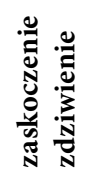 & 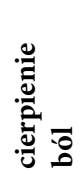 & 壱 & 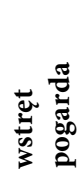 & 旡 & 롤 \\
\hline $\begin{array}{l}\text { Facebook } \\
\text { Крым Реалии }\end{array}$ & 1 & 0 & 0 & 0 & 0 & 0 & 21 \\
\hline suma & 8 & 0 & 3 & 0 & 5 & 1 & 64 \\
\hline $\begin{array}{l}\text { Vkontakte } \\
\text { Україна - } \\
\text { понад усе! }\end{array}$ & 1 & 1 & 1 & 1 & 0 & 0 & 18 \\
\hline $\begin{array}{l}\text { Vkontakte } \\
\text { Новости } \\
\text { Донбасса }\end{array}$ & 3 & 1 & 1 & 1 & 0 & 2 & 12 \\
\hline $\begin{array}{l}\text { Vkontakte } \\
\text { Крым }\end{array}$ & 5 & 2 & 0 & 1 & 2 & 1 & 12 \\
\hline $\begin{array}{l}\text { Vkontakte Ми } \\
\text { Українці }\end{array}$ & 3 & 3 & 1 & 0 & 0 & 0 & 5 \\
\hline suma & 12 & 7 & 3 & 3 & 2 & 3 & 57 \\
\hline
\end{tabular}

Źródło: opracowanie własne

Spośród innych stanów emocjonalnych fotografowanych osób wyróżniają się pozytywne odczucia zadowolenia. Łącza się one z odnoszonymi sukcesami, wiarą w swoją siłę, zwycięski entuzjazm, a także świadomością modeli „bycia fotografowanym".

Kolejna kategoria dotyczy miejsc geograficznych wydarzeń zarejestrowanych na zdjęciach.

Tab. nr 6 .

\begin{tabular}{|l|c|c|c|c|}
\hline \multicolumn{1}{|c|}{ Nazwa portalu } & Krym & Donbas & $\begin{array}{c}\text { Inna } \\
\text { miejscowośćl } \\
\text { front }\end{array}$ & Inne miejsce \\
\hline Facebook АнтиМайдан & 1 & 3 & 1 & 1 \\
\hline Facebook ЄвроМайдан & 0 & 4 & 6 & 17 \\
\hline Facebook Russian Сгімеа & 1 & 7 & 0 & 3 \\
\hline Facebook Крым Реалии & 21 & 0 & 0 & 5 \\
\hline
\end{tabular}




\begin{tabular}{|l|c|c|c|c|}
\hline suma & $\mathbf{2 4}$ & $\mathbf{1 4}$ & $\mathbf{7}$ & $\mathbf{2 6}$ \\
\hline $\begin{array}{l}\text { Vkontakte Україна - понад } \\
\text { yce! }\end{array}$ & 0 & 7 & 4 & 14 \\
\hline $\begin{array}{l}\text { Vkontakte Новости } \\
\text { Донбасса }\end{array}$ & 2 & 6 & 5 & 11 \\
\hline Vkontakte Крым & 7 & 1 & 0 & 6 \\
\hline Vkontakte Ми Українці & 0 & 2 & 1 & 3 \\
\hline suma & $\mathbf{9}$ & $\mathbf{1 6}$ & $\mathbf{1 0}$ & $\mathbf{3 4}$ \\
\hline
\end{tabular}

Źródło: opracowanie własne

Główne miejsca konfliktu (z pominięciem kategorii inne) utrwalone na fotografiach pokrywają się z aktywnościami militarnymi walczących stron. Są nimi Krym i Donbas. Na portalu Facebook więcej miejsc związanych jest z Krymem, na Vkontakte z Donbasem. Nie są to jednak liczebności znacznie różniące się między sobą. Mogą wskazywać na większe zainteresowanie Krymem „zewnętrznych” użytkowników Facebooka. W przypadku Vkontakte zwróconego do rosyjskojęzycznego audytorium ważniejszym strategicznie miejscem w przebiegu konfliktu okazał się Donbas.

W zamierzeniu badawczym jednym z celów było dookreślenie funkcji analizowanych fotografii, zebranych w trzy kategorie: czysto informacyjna (neutralna) i intencjonalnie ocieplająca wizerunki stron konfliktu. Poniżej kilka przykładów ocieplającej funkcji fotografii:

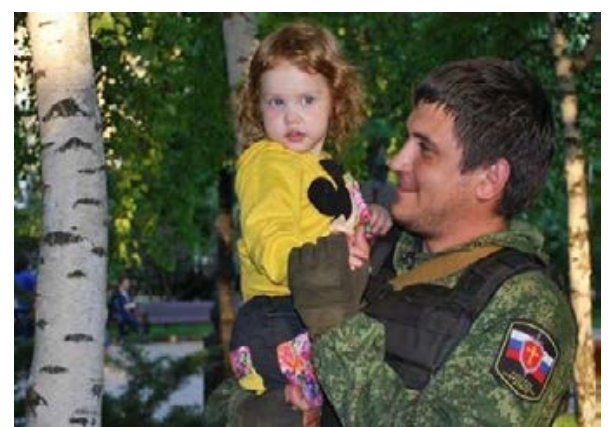

Facebook Russian Crimea

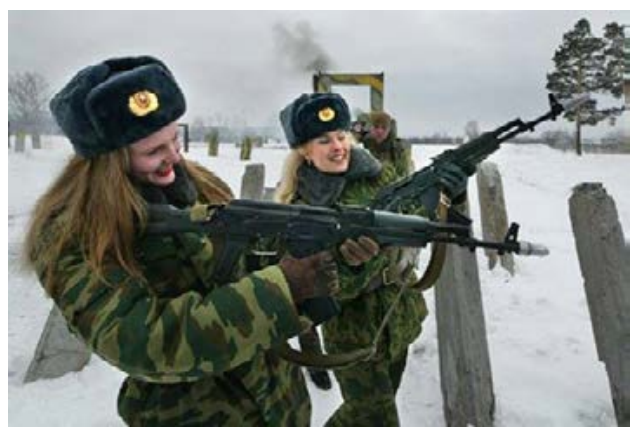

Facebook Russian Crimea 


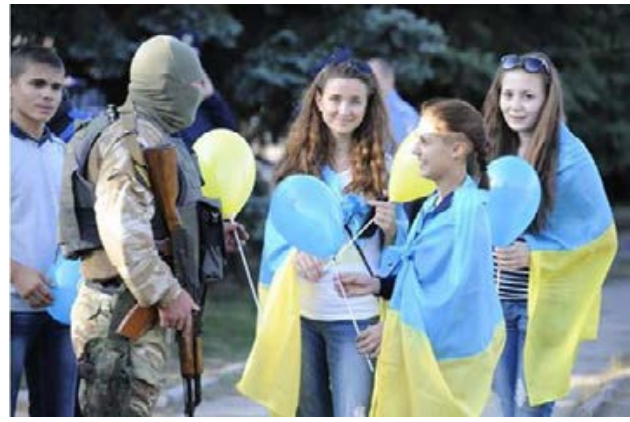

Facebook ЄвроМайдан

Poniżej w tabeli zaprezentowano liczebny rozkład „ocieplających” fotografii:

Tab. nr 7.

\begin{tabular}{|c|c|c|c|}
\hline \multicolumn{4}{|c|}{ Funkcje fotografii } \\
\hline Nazwa portalu & $\begin{array}{c}\text { informacyjna } \\
\text { neutralna }\end{array}$ & $\begin{array}{c}\text { ocieplenie } \\
\text { wizerunku Rosjan }\end{array}$ & $\begin{array}{c}\text { ocieplenie } \\
\text { wizerunku Ukraińców }\end{array}$ \\
\hline Facebook АнтиМайдан & 7 & 2 & 1 \\
\hline Facebook ЄвроМайдан & 28 & 0 & 8 \\
\hline Facebook Russian Crimea & 0 & 26 & 0 \\
\hline Facebook Крым Реалии & 35 & 0 & 1 \\
\hline suma & 70 & 28 & 10 \\
\hline $\begin{array}{l}\text { Vkontakte Україна - } \\
\text { понад усе! }\end{array}$ & 23 & 0 & 8 \\
\hline $\begin{array}{l}\text { Vkontakte Новости } \\
\text { Донбасса }\end{array}$ & 19 & 7 & 0 \\
\hline Vkontakte Крым & 10 & 12 & 0 \\
\hline Vkontakte Ми Українці & 4 & 0 & 12 \\
\hline suma & 56 & 19 & 20 \\
\hline
\end{tabular}

Źródło: opracowanie własne

Funkcja informacyjna analizowanych fotografii uplasowała się na pierwszym miejscu, co jest zrozumiałe bowiem fotografie przyczyniają się do kreowania wiedzy o konflikcie. Funkcja ocieplania wizerunku podmiotów - stron w konfliktu rozkłada się niemal równomiernie na portalu Vkontakte, na portalu Facebook zdecydowanie częściej umieszczane są fotografie ukazujące Rosjan w pozytywnym kontekście. 


\section{Realizm czy manipulacja w narracjach wojennych}

- strategie przekazów wojennych

Pogłębiona analiza semiotyczna polegająca na odczytaniu znaczeń na fotografiach pozwoliła na wyróżnienie i scharakteryzowanie podstawowych strategii przekazu wiedzy o wojnie w których fotografie stały się narzędziami ich współtworzenia.

\section{Strategia chaosu informacyjnego}

Niektóre prezentowane na fotografiach treści intencjonalnie mają przyczyniać się do pobudzania wątpliwości i niepewności opinii publicznej. Strategia wzbudzania niepewności informacyjnej najbardziej zauważalna jest na Facebooku w grupie Facebook АнтиМайдан.

Możemy tu mówić o dwóch sferach chaosu informacyjnego na fotografiach: militarnej i politycznej. Sfera militarna dotyczy działań wojennych obu stron. Pierwszym przykładem jest fotografia portretowa i przypadek ukraińskiego żołnierza w randze kapitana, który wprowadził swój oddział do Rosji i sam przeszedł do obozu rosyjskiego. Nie można jednak odnaleźć informacji co stało się z podległymi mu ukraińskimi żołnierzami. Inny przykład związany jest $\mathrm{z}$ chaosem informacyjnym panującym w środowisku medialnym. Dotyczy wydarzeń jakie miały miejsce 9 maja $2014 \mathrm{r}$. w Mariupolu i informacji podawanej przez ukraińskie media СМИ о ataku donbaskich separatystów na proukraińskich mieszkańców Marienpola. Fotografia przedstawia czołg dowodzony przez separatystów DNR jadący ulicami Mariupola. Na drodze czołgu stoją cywile. Informacja przekazana w mediach (udokumentowana zrzutem ekranowym) mówi o strzelaniu z czołgu do spokojnych mieszkańców Mariupola. Dołączony materiał filmowy z komentarzem $^{12}$ dementuje te informacje. Film pokazuje, że to mieszkańcy „atakują” czołg uniemożliwiając mu przejazd. W filmie wskazano także na kłamstwo o tym, że wcześniej separatyści przejęli ten czołg, bowiem numer zdobytego i tego o którym mowa w tym wydarzeniu nie zgadzają się (Facebook АнтиМайдан).

Wprowadzanie chaosu informacyjnego $z$ użyciem fotografii w drugiej sferze politycznej łączy się z konkretnymi komunikatami polityków. Użytkownicy umieszczają portrety polityków wypowiadających wątpliwe, nieudokumentowane i dość absurdalne kwestie. Pierwszym przykładem jest umieszczona fotografia Julii Tymoszenko i jej słowa: Poroszenko jest agentem Kremla (Facebook АнтиМайдан), która ma sugerować skonfliktowanie na szczytach władzy na Ukrainie. Inny przypadek to fotografia ministra Ławrowa i kadr z jego konferencji prasowej. Rosyjski minister podważa autentyczność amerykańskich zdjęć satelitarnych ukazujących wkroczenie wojsk rosyjskich na obszar Ukrainy,

12 Autor komentarza Анатолий Шарий jest prorosyjskim ukraińskim dziennikarzem 
nazwał je symulacjami komputerowymi (Facebook АнтиМайдан). Тa fotografia wpisuje się w strategię zaprzeczania militarnego zaangażowania w konflikt we wschodniej Ukrainie przez władze rosyjskie.

\section{Strategia zastraszania, potęgowania lęku}

Strategia zastraszania na portalach $\mathrm{z}$ wykorzystaniem fotografii obejmuje cztery sfery aktywności: militarną, ideologiczną, polityczną i ekonomiczną. Fotografie przyporządkowane tej strategii odnaleźć można na Facebooku w grupach dyskusyjnych: Facebook АнтиМайдан i Facebook Крым Реалии oraz na portalu Vkontakte na forach: Vkontakte Україна - понад усе! oraz Vkontakte Ми Українці. Najbardziej wyraziste i łatwe w odczycie są fotografie ze sfer działań militarnych i ideologicznych. W dziedzinie militarnej zastraszanie przyjmuje formę pokazu siły, potęgi i nowoczesnego wyposażenia wojsk rosyjskich, oddziałów Berkutu, rzadziej ukraińskich. Cechy te wizualizowane są najczęściej konwojami rosyjskich czołgów i wozów opancerzonych: rosyjskich (Facebook АнтиМайдан, Facebook Russian Crimea, Facebook Крым Реалии) i ukraińskich (Vkontakte Україна - понад усе!, Vkontakte Ми Українці).

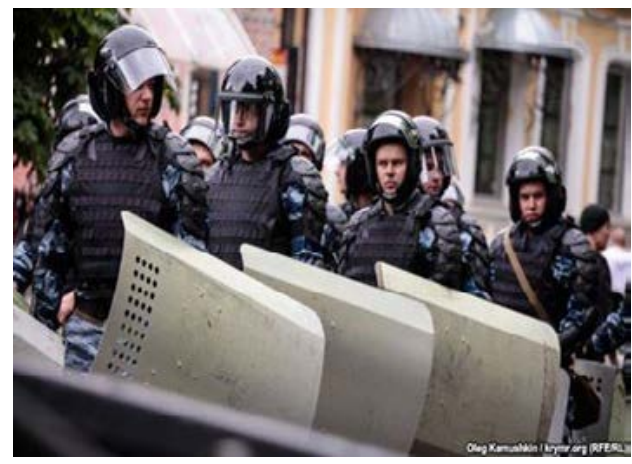

Facebook Крым Реалии

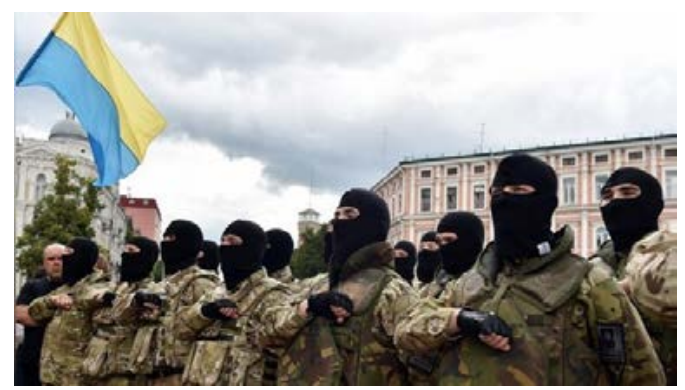

Vkontakte Новости Донбасса

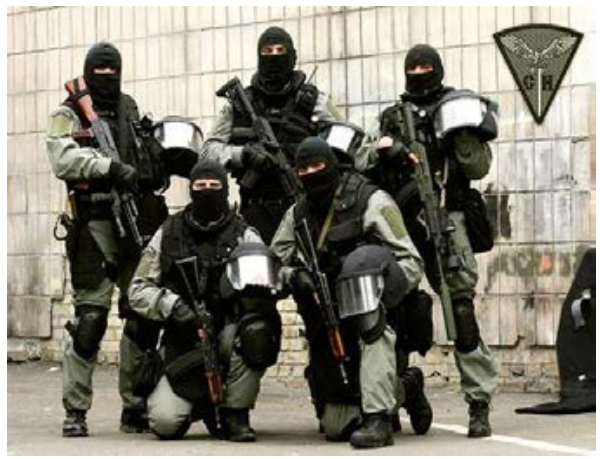

Vkontakte Новости Донбасса

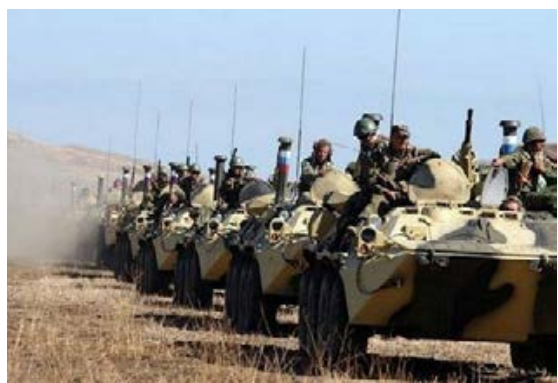

Facebook ЄвроМайдан 
Portretowani żołnierze są zamaskowani osłonami twarzy - czarnymi lub w kolorze panterki, co pozwala im czuć się anonimowymi, ale także bardziej groźnymi, nieprzewidywalnymi, bezkarnymi za czyny. Z pola walki znika tradycyjny mundur identyfikujący narodowość i rangę żołnierza - właściwie trudno odróżnić na podstawie umundurowania, po której stronie walczy. Symbolem wyróżniającym stronę rosyjską i prorosyjskich separatystów jest przyczepiona do uniformu wstążka św. Jerzego.

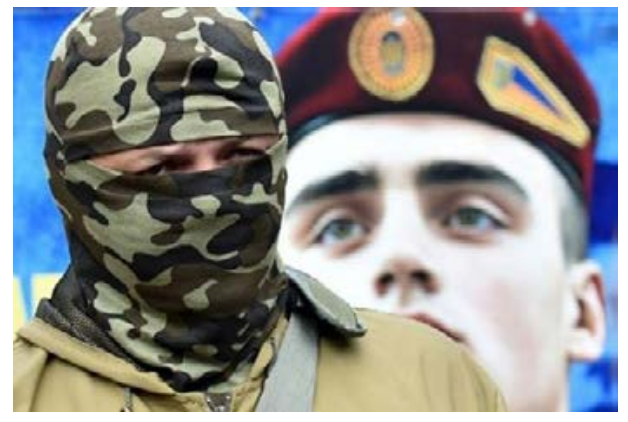

Facebook ЄвроМайдан

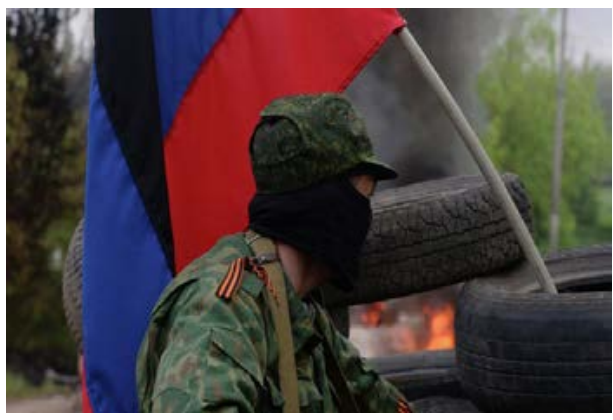

Vkontakte Новости Донбасса

W sferze aktywności ideologicznej wzbudzenie lęku polega na eksponowaniu symboliki nazistowskiej u Ukraińców. Przykładem są zdjęcia nazistowskich gestów Sieg Heil, zaciśnięte pięści uniesione w górę, a także symbolika niektórych formacji sił politycznych Ukrainy nawiązujących do nazistowskich symboli np. emblemat batalionu Gwardii Narodowej Ukrainy „Donbas”, symbole organizacji neobanderowskich i Prawego Sektora - m. in. Wolfsangel (Facebook АнтиМайдан, Vkontakte Новости Донбасса).

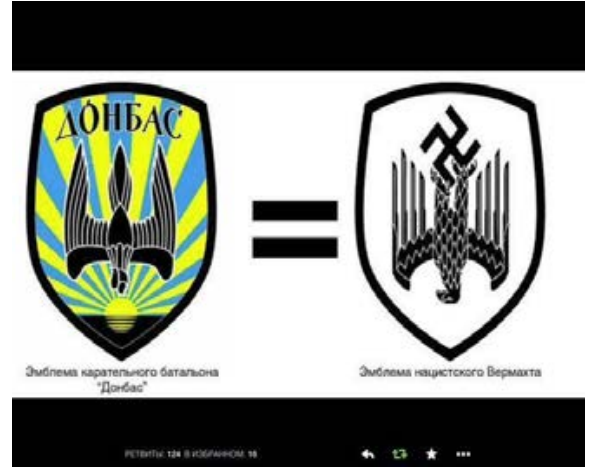

Facebook АнтиМайдан

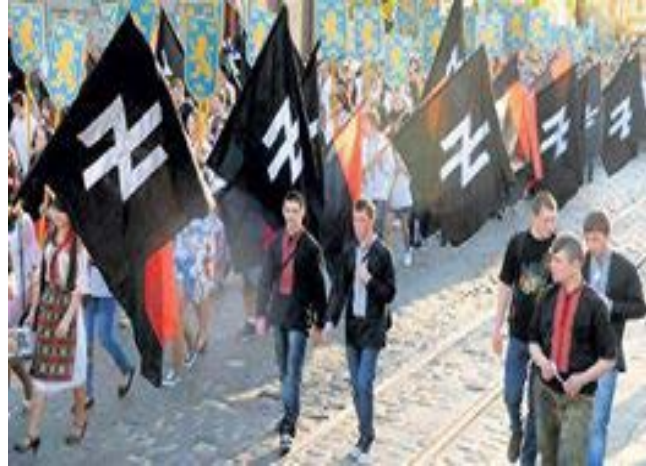

Facebook АнтиМайдан

W sferze działalności polityczno-ekonomicznej fotografowani politycy wypowiadają groźby różnego rodzaju. Arsenij Jaceniuk grozi utrudnieniami w dosta- 
wach rosyjskiego gazu do Europy (Fecebook АнтиМайдан), Sergiej Aksionow grozi firmom płacącym podatki Ukrainie (Facebook Крым Реалии), prezydent Petro Poroszenko stylizowany jest na bezwzględnego polityka silnej ręki wymuszającego bezwarunkowe posłuszeństwo (Vkontakte Україна - понад усе).

\section{Strategia utrwalania wizerunku wroga}

Każdy $\mathrm{z}$ analizowanych portali buduje i utrwala określony wizerunek wroga w zależności od audytorium do którego jest skierowany. Na portalu Facebook w grupie АнтиМайдан fotografie multiplikują i eksponują ukraiński nacjonalizm. Publikowane są historyczne fotografie, np. ukraińskie kobiety we Lwowie witające hitlerowców w $1941 \mathrm{r}$. gestem Sieg Heil, fotografie dokumentujące zbrodnie oddziałów UPA podczas rzezi wołyńskiej na polskiej ludności. Inne publikowane materiały rejestrują współczesne wydarzenia - manifestacje neobanderowców z portretem Stepana Bandery, wieszanie flagi ze swastyką obok ukraińskiej, fotografie skandujących swoje hasła młodych Ukraińców.

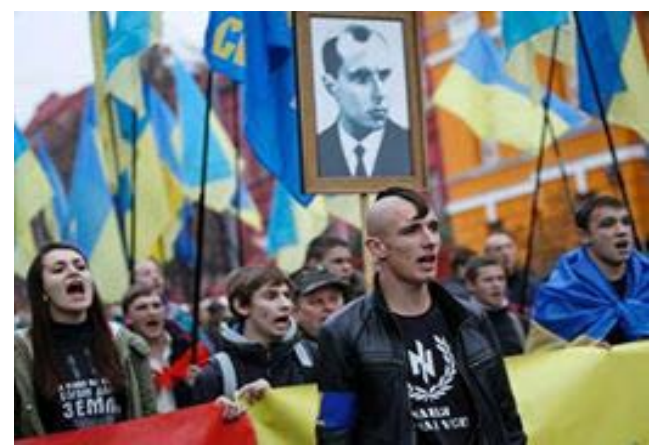

Facebook АнтиМайдан

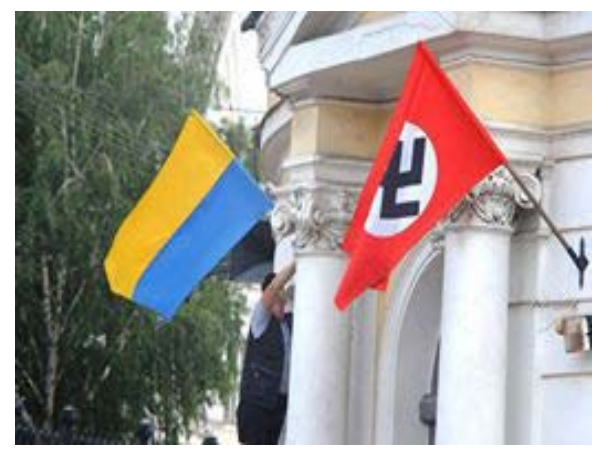

Facebook АнтиМайдан

Na Vkontakte Новости Донбасса można znaleźć zdjęcia brutalnych zachowań członków Prawego Sektora oraz eksponujące brak ducha waleczności u żołnierzy ukraińskich np. zdjęcie żołnierzy ATO w czystych mundurach, świecących kaskach i komentarz sugerujący, że żołnierze są na fotosesji.

Na portalach Facebook Russian Crimea, Vkontakte Новости Донбасса, Vkontakte Крым Zamieszczone materiały wizualne tworzą wizerunek potężnej, silnej militarnie armii rosyjskiej. Taki wizerunek dezawuowany jest na Vkontakte Україна - понад усе!, poprzez zamieszczony kolaż zdjęć pokazujących brutalizację zachowań służb rosyjskich, przejawiającą się przemocą fizyczną wobec manifestujących cywilów, w tym kobiet. 


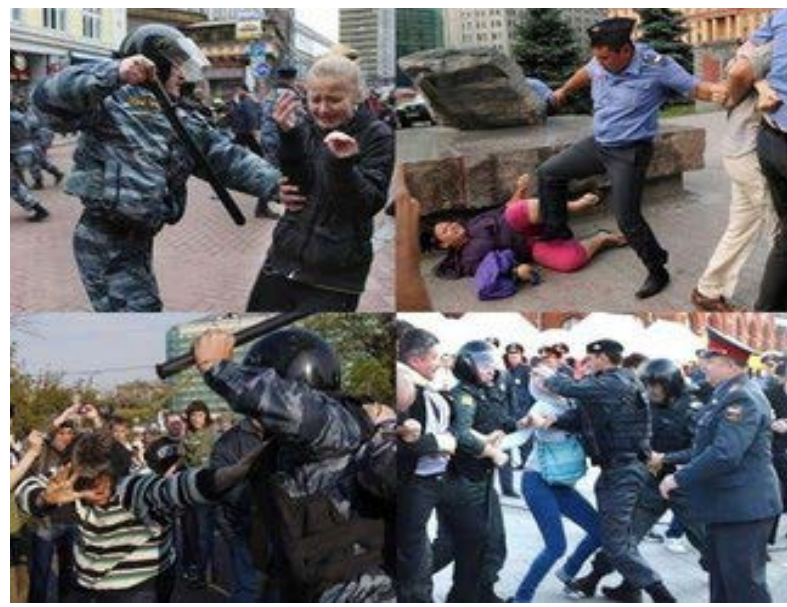

Vkontakte Україна понад усе!

\section{Wnioski}

Wizualne postrzeganie rzeczywistości generuje nowe formy percepcji, nową składnię myślenia i wrażliwości. Dostrzeżone bowiem zostało, że formy komunikowania poprzez które określamy rzeczywistość i tworzymy wiedzę o sobie samym oraz o otaczającym świecie, są w znaczącej mierze spełniane przez techniczne medium obrazowania, a pierwszym $\mathrm{z}$ nich okazała się właśnie fotografia ${ }^{13}$. Dla przeciętnego odbiorcy fotografia jest przekazem bez ukrytego kodu, obiektywnym oddaniem realiów świata. Medialnie zapośredniczony obraz stanowi nie tylko informację o rzeczywistości, ale przede wszystkim jej wzorzec. Obraz zyskuje w ten sposób przewagę nad rzeczywistością, ponieważ może modelować i porządkować świat zgodnie z kryteriami i kanonami obowiązującymi w danej kulturze. Każdy komunikat wizualny zawiera kulturowo uwarunkowane wytyczne, dotyczące sposobu prezentowania treści, które składają się na wzór wizualnej rzeczywistości społecznej.

Głównym zagadnieniem niniejszego artykułu była próba odtworzenia fotograficznej narracji wizualnej zbrojnego konfliktu rosyjsko-ukraińskiego na popularnych wśród Ukraińców i Rosjan portalach Facebook i Vkontakte.

Podjęte refleksje pokazały, że fotografie upubliczniane w mediach społecznościowych można uznać za swoisty paradygmat wizualnych narracji opisujących

${ }_{13}$ A. Łukaszewicz, Ku nowemu obrazowi świata. Obraz cyfrowy - dynamiczna percepcja doświadczenia? w: Obrazy i obrazowanie w dobie mediów elektronicznych, red. V. Sajkiewicz, Katowice 2010 s. 73-74. 59-67 
współczesne konflikty wojenne. Wyznacznikami tych narracji stały się stylistyka i formy kompozycyjne fotograficznej dokumentacji działań wojennych. Zarówno na portalu Facebook jak i na Vkontakte dominują fotografie informacyjne: sytuacyjne i portretowe. Te gatunki najlepiej oddające procesualny tj. rozwojowy charakter konfliktu i jednocześnie dokumentujące głównych bohaterów konfliktu: cywilów, dowództwo militarne i władze polityczne. Na obu portalach dominują dwie grupy zdjęć: anonimowe bez podania autora oraz fotografie pochodzące ze źródeł zewnętrznych. Źródłami zewnętrznymi są adresy stron internetowych lub konkretne linki użytkowników, z których rekapitulowane są materiały na posty. Na fotografiach najczęściej pojawiają się politycy, cywile i dopiero w dalszej kolejności żołnierze. Wizualizacje polityków jako aktorów konfliktów wojennych wskazują także na fakt, że współczesne wojny w mediach wytwarzają iluzję niezbędności polityki jako podstawowego elementu strategii wojennych. Zanika też klasyczny podział na żołnierzy i cywilów, mundur znika z pola walki - każdy członek społeczeństwa jest lub może stać się żołnierzem realnie lub potencjalnie. Śmierć i zabijanie nie są eksponowane na fotografiach.

Analiza własna pozwoliła na wyróżnienie i scharakteryzowanie podstawowych strategii przekazu wiedzy o wojnie w których fotografie stały się narzędziami ich współtworzenia. Strategia chaosu informacyjnego pozwala ustalić, że niektóre prezentowane na fotografiach treści intencjonalnie przyczyniały się do pobudzania wątpliwości i niepewności opinii publicznej. Można mówić o dwóch sferach chaosu informacyjnego na fotografiach: militarnej i politycznej. Strategia zastraszania i potęgowania lęku na portalach z wykorzystaniem fotografii obejmuje cztery sfery aktywności: militarną, ideologiczną, polityczną i ekonomiczną, natomiast strategia utrwalania wizerunku wroga wyraża się tym, że każdy $\mathrm{z}$ analizowanych portali intencjonalnie buduje i utrwala określony wizerunek wroga $\mathrm{w}$ zależności od audy torium do którego jest skierowany.

Poruszane zagadnienia $\mathrm{z}$ pewnością nie zostały wyczerpane $\mathrm{w}$ tekście w wymiarze mediów społecznościowych dynamika i nieprzewidywalność ich rozwoju otwiera szereg kontekstów, które stanowić mogą horyzont odniesień dla dalszych naukowych eksploracji podjętego tematu.

\section{Bibliografia}

Barker Ch., Studia kulturowe. Teoria i praktyka, Kraków 2005.

Framing of the Ukraine - Russia conflict in online and social media, red. Robert Szwed, Ryga 2016.

Hopfinger M., Kultura współczesna - audiowizualność, Warszawa 1985.

Kurowicki J., Fotografia jako zjawisko estetyczne, Toruń 2000.

Łukaszewicz A., Ku nowemu obrazowi świata. Obraz cyfrowy - dynamiczna percepcja doświadczenia?, w: Obrazy i obrazowanie w dobie mediów elektronicznych, red. V. Sajkiewicz, Katowice 2010, s. 59-67. 
Manovich L., Paradoks fotografii cyfrowej, w: Fotospołeczeństwo. Antologia tekstów z socjologii wizualnej, red. M. Bogunia-Borowska, P. Sztompka, Kraków 2012, s. 536-549.

Murray S., Czy fotografie mówią prawdę, w: Fotospołeczeństwo. Antologia tekstów z socjologii wizualnej, red. M. Bogunia-Borowska, P. Sztompka, Kraków 2012, s. 468-487.

Rouille A, Fotografia między dokumentem a sztuka współczesną, Kraków 2007.

Villi M., Matikainen J., Wiadomość zdjęciowa jako forma komunikacji wspólnotowej, w: Fotospołeczeństwo. Antologia tekstów z socjologii wizualnej, red. M. Bogunia-Borowska, P. Sztompka, Kraków 2012, s. 516-535.

Szulich-Kałuża J., The role of visualization in social-media information campaigns, w: Framing of the Ukraine - Russia conflict in online and social media, red. Robert Szwed, Ryga 2016, s. 83-117.

Yee-Kuang $\mathrm{H}$., The "transformation of war" debate: Through the looking glass of Urlich Beck's World Risk Society, „International Relations", 2006, vol. 20, no.1, s. 69-91.

\section{Netografia:}

https://www.facebook.com/RussianCrimea

https://www.facebook.com/EuroMaydan

https://www.facebook.com/radiosvobodakrym.org

http://vk.com/sdamnaleto

http://v.com/budspravjnimukraincem

http://vk.com/vosto4nuyfront

http://vk.com/revolution

\section{Streszczenie}

Tematem artykułu są refleksje dotyczące fotografii jako narzędzia medialnego, upowszechniającego wiedzę o współczesnych konfliktach wojennych na przykładzie fotografii konfliktu na wschodniej Ukrainie. W analizie fotografii wykorzystano technikę ilościowej analizy zawartości oraz analizę semiotyczną. Na potrzebę analizy ilościowej opracowano klucz kategoryzacyjny, obejmujący kategorie formalne i merytoryczne służące do opisu zdjęć. Analizą szczegółową objęte zostały fotografie, które użytkownicy umieścili na wyselekcjonowanych postach portali społecznościowych Facebook i Vkontakte w okresie od 1.04.2014 r. do 31.12.2014 r. Ogółem materiał badawczy stanowiło 197 fotografii, w tym 112 opublikowanych na portalu Facebook i 85 na portalu Vkontakte. Wyniki analiz własnych posłużyły do poszukiwań odpowiedzi na pytania bardziej szczegółowe, których zakres zamknąć można w następujących polach problemowych: stylistyka i formy kompozycyjne fotograficznej dokumentacji działań wojennych, realizm czy manipulacja w fotograficznych narracjach wojennych, charakterystyka strategii przekazów wojennych w mediach społecznościowych.

Słowa kluczowe: fotografia wojenna, media społecznościowe, analiza zawartości, analiza semiotyczna. 


\section{The photography as a tool for mediating war in social media - an example of the conflict photographs in eastern Ukraine}

\section{Summary:}

The subject of the article relates to reflections on photography as a media tool, disseminating knowledge about contemporary war conflicts on the example of the photographs of conflict in eastern Ukraine. To analyse the photography quantital content-analysis and semiotic analysis techniques were employed. For the needs of quantitative analysis, a categorizing key was elaborated, which included form and substance categories to describe photographs. The detailed analysis covered all the photos that users posted on Facebook and Vkontakte social networking posts from 1.04.2014 to 31.12.2014. In all, the research material consisted of 197 randomly selected photographs, 112 published on Facebook and 85 on Vkontakte. The results of own analyses were used to find answers to more detailed questions, which can be closed in the following problem areas: stylistic and composite forms of photographic documentation of warfare, realism or manipulation in photographic narratives of the war, characteristics of war strategy in social media.

Keywords: the war photography, social media, content analysis, semiotic analysis. 